\title{
NOVEL IMAGES IN THE IMAGERY SPACE OF AMERCAN POETIC DISCOURSE: A COGNITIVE PERSPECTIVE
}

\section{Bieliekhova L. I.}

\section{INTRODUCTION}

The change of paradigms in the study of a text as a verbal object from language-centered through text-centered to knowledge-centered - has brought to the forefront the assumption that text formation as well as the function of textual elements are regulated by certain cognitive mechanisms.

This research focuses on revealing the nature of verbal poetic image from a cognitive perspective and aims at building an original typology of images in American poetry. It highlights cognitive mechanisms that lead to the emergence of novel poetic images which cause a possible breakthrough in the conceptualization of the world. In the framework of cognitive linguistics a poetic image is viewed as a textual construal and a cognitive structure which has two planes - conceptual and verbal. The conceptual plane of the image is understood as a unity of the eidetic (holistic) and the logical (discrete). The idea of discreteness has been laid at the basis of conceptual analysis of verbal poetic images within the framework of idealized cognitive models or image-schemas ${ }^{1}$.

Conceptual analysis of rich empirical data obtained from contemporary American poetry suggested figuring out two groups of verbal poetic images: the old (archetypes and stereotypes) and new ones (idiotypes and kainotypes).

In this article I share the view ${ }^{2}$ that the frequent use of a particular kind of verbal poetic image depends on the prevalence of a certain type of artistic conscience (mythological, traditional, rational or irrational, and modern individually-creative) as well as of the kind of poetic thinking (analogical, associative, paradoxical, parabolic, and essayistic) governing in the definite cultural period.

A poetic image is a verbal embodiment of the configuration of various conceptual schemas (metaphoric, metonymic and oxymoronic). Similar to

\footnotetext{
${ }^{1}$ Lakoff, George. Women, Fire and Dangerous Things : What Categories Reveal About the Mind. Chicago : University of Chicago Press, 1987. P. 67-72.

${ }^{2}$ Аверинцев С.С., Андреев М.Л., Гаспаров М.Л., Гринцер П.А. Категории поэтики в смене литературных эпох / Историческая поэтика. Литературные эпохи и типы художественного сознания. М. : Наследие, 1994. С. 3-38.
} 
the types of conceptual metaphors ${ }^{3}$ the paper suggests classification of conceptual oxymora. It is proved that the degree of novelty of verbal poetic images is predetermined by the type of conceptual oxymoron that underlies their verbal form.

The interpretation of a verse depends on the reader's background knowledge that presupposes his/her acquaintance with the prototypes inherent in a certain culture. A prototype is understood as a culturally dependent "best representative" of the category". In this research, the latter is regarded as a set of poetic isotypical (similar) images. All these images are presumed to descend to a definite archetype. In this paper archetype is treated as the concept shared by all humans, irrespective of their nationality, race and cultural code ${ }^{5}$. Archetype can be embodied in several prototypical images. Each of them underlies a number of idiotypes. Idiotype is a prototype's modification preferred by a particular writer. It is a complex image which reflects idiolect and idiostyle of the author, his peculiarities of world perception. Among idiotypes there can be found kainotypes, or the concepts the novelty of which provides a breakthrough into a new conceptual domain. In certain cases a clash between the image space of the archetype and the image space of the idiotype gives birth to a kainotype.

It is claimed that in the formation of a new meaning of a verbal image besides conceptual integration there exists amalgamation process which leads to the creation of novel type of metaphorical image - metabola.

\section{Mapping as a cognitive mechanism of verbal poetic images formation}

In cognitive linguistics, mapping is understood as the projection of knowledge structures from one conceptual sphere onto another, as an analogical mapping of attributes and properties of entities of a source domain onto ontologically related entities of a target domain ${ }^{6}$.

In addition to analogical, I determine other types of mapping, distinguishing between conceptual (analogical, substitutional, contrastive, narrative) and linguistic (constructive) one. Each type of mapping embodies a particular type of poetic thinking. That is, the basis of analogical (attributive, relational and situational) mapping constitutes analogous poetic thinking,

\footnotetext{
3 Лакофф Д., Джонсон М. Метафоры, которыми мы живём : Пер. с англ. / Теория метафоры. М. : Прогресс, 1990. С. 387-415.

${ }^{4}$ Rosch E. Principles of categorization /Cognition and Categorization: Ed. by E. Rosch and B.B. Lloyd. Hillsdale (N.J.) : Lawrence Erlbaum Associates, 1977. P. 27-48. Taylor J. R. Linguistic Categorization: Prototypes in Linguistic Theory. L., N.Y. : Routledge, 1995. P. 12.

${ }^{5}$ Юнг К. -Г. Архетип и символ. М. : Renaissance, 1991. С. 71.

${ }^{6}$ Fauconnier, Gilles. Mappings in Thought and Language. Cambridge (Mass.) : Cambridge Univ. Press., 1994. P. XXI.
} 
which allows you to project the attributes, relations, states, and events of one conceptual domain of the image onto another: "The shoots green as paint and leaves like tongue" (Logan NA, 315); In the verbal poetic image: "the acacia-like lady / shivering at the touch of a hand" (Moore WW, 77), - the image of a gentle, tender woman is created by mapping the attributes of acacia tree (shivering) on the similar movements of a woman. Relative mapping is mainly traced in the verbal images built on comparison: "days and seasons flit before the mind / as flit the snow-flakes in winter storm" (Bryant NA, 175) "Mist came up like a man's hand, / Fog lifted like a woman's shawl" (Sandburg CP, 733). Situational mapping as a kind of attributive analogical one lies in projecting similar states or actions from source domain of the image onto its target: "My anguished spirit, like a bird / Beating against my lips I heard" (Millay MV, 468); "An old man in love is a flower in winter" (Sandburg CP, 502).

Substitutional mapping is understood as replacing the whole with a part, or part with a whole via the implementation of associative poetic thinking: "There'll be many a dry eye at his funeral" (Sandburg CP, 489); "And a thousand shrugs and hoots / Met him in the shoulders and mouths he passed" (Sandburg CP, 144). As a rule, such poetic images are built on metonymies.

Paradoxical poetic thinking serves as the basis for contrastive mapping ${ }^{7}$, as a result of which one structure of knowledge collides or clashes with the other: "My father moved through griefs of joy" (cummings MV, 388); "The sinful pleasures I doe hate" (Bradstreet OB, 7); "They are light on the tresses, / But lead on the heart" (Poe OB, 202); "And under pain, pleasure / Under pleasure pain lives" (Emerson OB, 85).

Narrative mapping is seen as projecting the plot or motive of a literary text, historical or everyday life event onto the content of a poetic image by rethinking them via parabolic or essayistic poetic thinking": "She stared at him in a "Et-tu-Brutus" look "(Snyder OB, 567); "From your 'even-youBrutus' look / Amazed and stunned I stood”" (Willey BBAP, 406)

And, finally, constructive mapping is interpreted in this work as playing up the potential syntagmatic and paradigmatic properties of language units by projecting them onto the semantic-syntactic structure of a verbal poetic image": "He sang his didn 't and danced his did "(cummings SP, 271).

\footnotetext{
${ }^{7}$ Бєлєхова Л.І. Словесний поетичний образ в історико-типологічній перспективі : лінгвокогнітивний аспект (на матеріалі американської поезіі). Херсон : Айлант, 2002. С. 188-190; Маріна О.С. Семіотика парадоксальності у когнітивно-комунікативному висвітленні. Херсон : Айлант, 2015. С. 136.

${ }^{8}$ Turner M. The Literary Mind : The Origin of Thought and Language. N.Y.; Oxford : Oxford University Press, 1998. P. 253-289.

${ }^{9}$ Бєлєхова Л.І. Словесний поетичний образ в .... С. 178-207.
} 
The mechanisms for creating novelty of a verbal poetic image rediscovered by identifying linguistic-cognitive processes, operations and procedures that ensure their formation and functioning in a poetic text. A verbal poetic image as a three-dimensional entity flexibly changes its contours depending on the cognitive and linguistic operations that dominate the formation of the image, on the type of poetic thinking that determines the nature and direction of mapping.

\section{Typology of verbal poetic images}

Subcategorization of any type of image in the imagery space is carried out according to the functional criterion taking into account the types of mapping that underlie the formation of a particular image.

In this work, verbal poetic images are considered archetypal, if they reflect the mythopoetic picture in American poetry. They are classified into plot-images and symbol-images in which mythological, biblical and folklore knowledge of the world is embodied through narrative mapping. Archetypal verbal poetic images-symbols are characterized by suggestive function. The latter is understood as the way for creation emotiveness, which arises as a result of the use of ambivalent characters, leading to slowing down the information processing. For example, to comprehend the verbal poetic image "Life is a bowl of cherries" (Sandburg CP, 660) knowledge of the content of symbols in the Anglo-Saxon and Scandinavian traditions is necessary, where cherries, like an apple, symbolize the fruits of the knowledge of good and evil.

Archetypal verbal poetic images-plots fulfill a cognitive and creative function, as far as they reflect the mythopoetic picture of the world. They contribute to the activation of background, cultural and encyclopedic knowledge. For example: "Elija rode up into the sky in a chariot of fire" (Sandburg CP, 431).

The core of archetypes is the mythologeme. The development of the mythologeme is carried out by means of narrative mapping through parabolic comprehension of plots, motives and symbols contained in the Bible, myths and masterpieces of world culture. Markers of archetypal images are proper names and citations from the above mentioned sources, The verbal poetic archetypal images are used by poets as a stylistic device of allusion. Given that, in the verbal poetic image: "Mother Marie Theresa / Like Proserpina, who fell / Six months a year from earth to flower in hell" (Lowell, MV , 344), - the image of Mother Teresa is created by using an allusion to the archetypal plot about the Roman goddess of vegetation Proserpine, an analogue of the Greek goddess Persephone, which symbolizes the annual rebirth of nature, fertility, kindness and charity. 
Narrative mapping of the archetypal plot involves its projection onto the verbal poetic image both in unchanged and rephrased form. For instance, G. Longfellow uses a direct quotation from the Bible "Life is real! Life is earnest! / And the grave is not its goal; / Dust thou art to dust returnest, / It was not spoken of the soul" (Longfellow NA, 123). In C. Sandberg's verbal poetic images, Bible quotations are adapted to modern English: "Dust to dust, and ashes to ashes and then an old silence and a useless silence" (Sandburg CP, 26) and are used to create irony: "Ashes to Ashes, Dust to Dust, If the Women Don't Get You Then The Whiskey Must" (Sandburg CP, 460).

Archetypal poetic images play an important role in intertextual links, they unfold the frontiers of the texts establishing connections in space and time.

A stereotypal verbal poetic image is defined on the criteria of function and frequency of usage. A poetic image acquires a status of stereotype due to the frequency of its use in a cultural community and the well-established identity of its authorship. It must be entrenched into the community conscience through generalization as a cognitive procedure and stereotyped intertextuality as a result of its frequent use by other poets. For instance, the stereotypal verbal image "the river of life" has a definite author (Homer) and frequent citation by different poets through centuries. Besides it descends to an archetypal image "the river of Lethe".

Stereotypal verbal poetic images are the result of collective unconscious that shape a poetic tradition. They are built on established poetic formulas that reflect syncretic, analogical and associative poetic thinking, embodied in constantly repeated epithets: "the blue clear sky", "the bright golden sun", "star eyes", "pearl fog", "the silver moon, "gloomy fate", "bitter days", "the doggy life", "sunny smile"; poetic comparisons: "cold as a stone"; "Pretty as a flower"; "As white as snow"; oxymora: "sinful pleasure", "painful pleasure", "sweet sorrow", "the living death".

Stereotypical verbal poetic images are divided into universal, culturally specific and authorial ones. To universal I refer the verbal poetic images, created with the help of constant and tautological epithets, in semantics of which one can trace the identity of the signs and properties described by the objects. For example, in stereotypal images "thundering noise" and "chilling cold", both components have the same meaning: "noise" and "cold" respectively.

Culturally specific stereotypal poetic images are formed by attributive mapping of certain properties of animals (zoonyms) and plants (phytonyms). In each language, phytonyms and zoonyms, besides their 
nominative meanings, are also endowed with symbolic ones that express the peculiarity of the people's world outlook. The identification of culturally specific verbal poetic images makes it possible to establish intercultural differences in poetic thinking. Culturally specific stereotypical verbal poetic images are the core of national culture, the center of the imagery space of American poetry. They reflect the main values of the American lifestyle and mentality.

I consider that authorship of such stereotypical poetic images have acquired aphoristic nature due to systematic citation in the works of other authors. The dialectics of the functioning of the stereotype is explained, on the one hand, by the fact that in their formation they borrow the paremeological fund of human culture, and on the other, they themselves strive to become winged expressions. For example, the source of the formation of Frost's verbal poetic image "Good fences make good friends" in the poem "Mending Wall" is the famous English proverb "My house is my castle". But over time, due to the simplicity of the syntactic structure and the presence of general knowledge of the author and the reader about a certain fragment of reality, the verbal poetic image of R. Frost entered the general cultural fund of the American people.

Among the stereotyped "winged" verbal images that I qualify as authorial ones, are those that embody universal human truths, and the following deserve special attention: "Publication is the auction of the Mind of Man" (E. Dickinson); "It is equal to live in a tragic land / To live in a tragic time" (W. Stevens); "He who is ridden by a conscience / Worries about a lot of nonscience" (O. Nash); "Purity is obscurity" (O. Nash); "Keep away from the little deaths" (C. Sandburg).

New images are as far removed as possible from the stereotype, these are cognitive and creative structures that lead to the emergence of a new figurative concept (idiotype) and a new node in the conceptual network of concepts (kainotype).

\section{The mechanisms of idiotypal and kainotypal verbal poetic images formation}

The reproduction of creative mechanisms of the novelty of verbal poetic image is carried out in this work using an integrative cognitive model, which includes a number of linguistic and cognitive processes, operations, and procedures which ensure comprehension of images in poetic texts. In idiotypal and kainotypal verbal poetic images, various linguo-cognitive processes and operations of creating novelty are traced.

The formation of idiotypal verbal poetic images is associated with linguo-cognitive processes of categorization and verbalization (mainly 
with linguo-cognitive operations of narrative and constructive mapping at the phonological, lexical-morphological and syntactic levels). At the same time, the creation of a kainotype image is characterized by pre-categorical linguo-cognitive processes and operations at the pre-conceptual and textual levels.

The novelty of idiotypal verbal poetic images at the conceptual level is provided by linguistic-cognitive operations of specialization and modification, leading to the transformation of prototypical conceptual schemas underlying stereotypical verbal poetic images. For example, the stereotypical verbal poetic image: "the river of life", the conceptual structure of which is represented by the prototypical LIFE IS A WATER FLOW schema, acquires originality and freshness in modern poetry due to a number of transformations in the conceptual and verbal forms of the image. Modification of the prototypical schema as a result of adding concepts QUALITY, MOVEMENT, INTENSITY ensures the formation of idiotypal verbal poetic images: "Life is a sticky river" (Milley); "Life's clear stream" (Frost); "A waterfall of nights" (Ashbery).

The main linguistic-cognitive operation of creating novelty at the verbal level is constructive mapping, that is, the projection of the potential properties of linguistic units on the verbal fabric of images in a poetic text. Given that, the creation of the novelty of the verbal poetic image "Life is a run-on sentence" (Finegan), based on the archetypal image "The Book of Life" is facilitated by replacing the object of the image embodied in the word book with a new sentence expressed by the polysemantic word sentence, and adding to it the meaning of running - run-on. The use of runon neologism as the epithet of the object of this verbal image and the polysemy of the word sentence itself give additional content to the whole image, as a result of which the latter can be interpreted as "Life is a running sentence, like a line in a text or on a computer monitor" (associative connection between words on-line and run-on) or as "Life is a sentence that is approaching."

In verbal poetic image of C. Sandburg: "The dead say nothing / And the dead know much / And the dead hold under the tongue / A locked-up story" (Sandburg) - the archetypal image " The Book of Life "gets a new interpretation thanks to the narrative mapping of the mythological plot about Charon. Transferring the souls of the dead across the river of oblivion Styx, he charged them a fee - a coin that they kept under their tongue - hold under the tongue. That is why during the funeral rite, the ancient Greeks put a coin under the tongue of the deceased - a fee to Charon for transporting the shadows into the world of dead. C. Sandberg's use of the phrase a locked-up story instead of the archetypal book of life 
and the allegory of a mythological plot (parabola) - the dead hold under the tongue - creates a novelty in the book of life image. Formation and understanding of the image as a "closed book of life, an exhausted life story, blocked information" and, ultimately, as value is achieved by parabolic reflection and compression of information about Charon's myth with the help of substitutional mapping of the properties of a coin to characterize the concept of "life".

The apogee of poetic creativity is not only a new coverage of old truths, but also the creation of a verbal poetic image that has no analogues, leads to a violation and even destruction of stable views on ordinary phenomena and life events, on processes occurring in the world, and causes a sudden insight into understanding the essence of things. Such a verbal poetic image I name a kainotype. It makes a "conceptual breakthrough" in the conceptual system of a human being due to the emergence of a new concept or a new meaning of the word. For example, in the verbal poetic image: "It was evening all afternoon" (Stevens MV, 348) a poetic image of sadness is created by clashing the antonyms evening and afternoon, resulting in an additional meaning in the word evening - sadness.

In the formation and understanding of kainotypes, three main directions are traced. The first two relate to new verbal poetic images, the meanings of which are localized within a single word or the whole verbal poetic image, their novelty is caused either by an elaboration of the meanings in nominative units, or the destruction of archetypal conceptual schemas. The third way to form the kainotype is to disperse its content in the imagery space of the entire text.

Given that let us analyze the mechanisms of formation of a new sense in the following verbal poetic images: "septemberings arms of the year" (cummings); "His april touch drove sleeping selves to swarm their fates" (cummings). The elaboration of a new meaning in the words septembering, and april is realized by converting a noun into an adjective.

The formation of kainotypes is carried out by the interaction of images in the entire imagery space of a poetic text. The subject of the kainotype image is, as a rule, in the title of the poem, and the object part of the verbal poetic image is scattered throughout the text.

The verse of Andrew Lawrence "Peoplization of America" will serve as an example for revealing the mechanisms of creating a kainotypal verbal poetic image :

I am part of that Power, not understood

Which always wills the Bad and always works the Good

Peoplization of america 
New page was turned

When Twins were ruined.

Binladenism up-turned

Great chain of being

Manunkind new messia cured

And strong you-i peoplize the living.

The meaning of the kainotype "the transformation of the American population into a nation, into an American nation, its "humanization" is promoted by a common misfortune that heals people from inhumanity, alienation" is formed as a result of interaction and mutual influence of all images of the poetic text.

The imagery space of the poem is built by convergence and divergence of images embodied in different types of verbal poetic images which are interconnected by juxtaposition. The latter is one of the means for the divergence of images in a poetic text. The stereotypal verbal poetic image "New page was turned" is the result of the convergence of conceptual metonymy: the page of life (PART) stands instead of life (WHOLE) and the conceptual metaphor of LIFE IS THE BOOK that underlies the archetypal image "The Book of Life", taken from the Bible "Another book was opened, which is the Book of Life" (Revelation 20:12). Placed in a strong position of the poetic text, this image serves as a reference point, vantage point in the perspectivization of the kainotype and in the strategy of reconstructing the imagery space of the poem.

The idiotypal verbal poetic image "Binladenism up-turned Great Chain of Being" contains metaphors and metonymy based on such basic conceptual schemas as: LIFE IS MOVEMENT and LIFE IS CONTENT (metaphorical), TERRORISM stands in place of EVIL (metonymic). At the verbal level, the metonymy of Binladenism is created as a result of the conceptual integration of the personification metaphor BEN LADEN IS EVIL and the identification metaphor TERRORISM IS EVIL embodied in the verbal fabric of the text using constructive and creative mapping of the language units Binladen and terrorism through a linguo-cognitive procedure of compression. Verbal expression Great Chain of Being means a set of basic conceptual metaphors through which being is conceptualized (G. Lakoff, M. Turner). This is a universal cultural code, the origins of which originate in antiquity. In the context of the poem, due to the interaction of the metonymy of Binladenism with the verb metaphor upturned Great Chain of Being and the association with well-known events caused by the poetic line When Twins were ruined, the analyzed verbal poetic image is filled with the content "The events of September 11 turned the normal course of American life, shook the Americans' faith in stability 
and the inviolability of their values." The destruction of the World Trade Center, located in the twin skyscrapers, symbolizes an attempt to destroy the belief in stability and the inviolability of the economic strength of the United States.

The divergence of images, because of which specific emotionality is embodied, creates the effect of intense expectation, due to the interaction of the idiotypical verbal poetic image-oxymoron "Binladenism, new messia" with the kainotype image-metaphor "And strong you-i peoplize the living". The convergence of images in a poetic text is provided by the linguistic-cognitive procedure of intertextualization, manifested in the use of images by E. Cummings manunkind, you- $i$ and the epigraph, in which Goethe's verbal poetic image "I am the one who always wants evil and always creates good" has something in common with the oxymoronic image "Binladenism - the new messiah, cured inhumanity". A frame composition created by placing in strong positions (at the beginning and at the end of the text) the verbal images of the same content and the verbal images "Peoplization of America" and "you-i peoplize the living" also contribute to the convergence of imagery space.

The specificity of the formation of the kainotype consists in the cooperaton of the author and the reader. The content of the verse is enriched with new meanings due to the background knowledge of the reader, i.e. due to the schemas of reinforcement and refreshment as structures of knowledge that are formed and activated during the reconstruction of the imagery space of a poetic text ${ }^{10}$. The reinforcement schema is realized thanks to stereotypes embodied in the images "New page was turned", "Great Chain of Being", as well as in the proverb "there would be no happiness unless misfortune". The schema of refreshment occurs due to the stylistic device of foregrounding realized by the use of neologisms of E. Lawrence peoplization, Binladenism, peoplize and E. Cummings you-i, which slow down text processing and require modification of linguocognitive operations and image formation procedures. The effect of defamiliarization $^{11}$, caused by different types of foregrounding ${ }^{12}$, creates a high degree of emotiveness of the poetic text, contributing to the increase of intensity, the so-called "emotional crescendo" 13 . The latter, in its turn, activates the revelation schema as a backstage knowledge structure that establishes a connection between categorial and pre-categorial operations.

\footnotetext{
${ }^{10}$ Semino, Elena "Schema theory and the analysis of text worlds". Language and Literature vol. No. 2, 1995. P. $79-108$.

${ }_{11}$ Шкловский В.Б. Гамбургский счет : Статьи, воспоминания, эссе. М. : Советский писатель, С. 61-63.

12 Арнольд И.В. Семантика. Стилистика. Интертекст. СПб. : Изд-во С.-Петербургского университета, 1999. C. 91-94.

${ }^{13}$ Tsur R. Toward a Theory of Cognitive Poetics. Amsterdam : Elsevier Science Publishers, 1992. P. 185.
} 
Revelation as a heuristic mechanism of creating a new meaning is an unconscious cognitive operation carried out in this poem by pre-categorial linguistic and cognitive procedures of constructive mapping: meaning of the suffixes ization, ize - action - is mapped on the noun people.

Given that, the presence in the poetic text of a kainotypal verbal poetic image activates the consolidation of knowledge schemas and contributes to the formation of new knowledge.

The study of verbal poetic images in the light of cognitive poetics with the use of interdisciplinary knowledge made it possible to identify the nature of the interaction between poetic thinking and its verbal embodiment and to state that we do not only "live by metaphors," we understand life by verbal poetic images.

A further research perspective may be a comparative study of the cognitive styles of various poets, the identification of cultural and synergistic features of verbal poetic images, contributing to the delineation of the cultural and value picture of the world in American poetry.

\section{Metabola as a novel verbal poetic image}

The formation of a new type of verbal poetic image - metabola - is caused by the tendency of poetic speech to convergence, which is expressed in the concentration of tropes and activation of stylistic figures within a certain segment of a poetic text, and divergence, manifested in the dispersal of images throughout the fabric of the poetic text, - in depriving the image of subject-sensual concreteness.

Features of the verbal poetic images of American poetry of postmodernism are determined by the prevailing artistic principles of this period, such as anthropocosmism, decentration of the text structure, eclecticism and fragmentation in the representation of the world, deconstruction ${ }^{14}$. The artistic techniques of modernism: collage, linguistic play, parody, irony, - acquire new qualities in postmodernism, thanks to the development of essayistic poetic thinking. The latter is understood as "thinking in different directions", as a result of which the fragmentary and eclectic descriptions in the text give it a panoramic view ${ }^{15}$. In my research, the essayistic form of poetic thinking is interpreted as a process of poetic comprehension of the real or possible world, as a result of which, through individually-creative refraction of the properties and signs of familiar objects, phenomena and life events obtain a new perspective of their vision

\footnotetext{
${ }^{14}$ Гассан І. Чим є постмодернізм і чим він стане? Літературний і культурний аспекти : Пер. 3 англ. / Американська література після середини ХХ століття : Матеріали міжнародної конференції, Київ, 25-27 травня 1999 року. К. : Довіра, 2000. С. 24.

15 Эпштейн М. Н. Постмодерн в русской литературе. М. : Высшая школа, 2005. С. 12, 84, 91, 375.
} 
or a new image is created. Essayistic thinking involves the use of different methods of artistic development of reality.

In American poetry of postmodernism, essayistic and parabolic poetic thinking led to the transformation of metaphor into metabola formed by the interweaving of the signified and the signifier. In the poetic speech of this period, alongside with the tendency to convergence of images, the opposite tendency is traced - divergence, which manifests itself in the dispersion of images throughout the fabric of the poetic text, which creates the effect of "diffused emotions", blurred emotiveness of the text. Divergence is interpreted in this work as the deployment of imagery space, leading to the creation of gestalt-free images, thing-free images ${ }^{17}$, that is, images devoid of concrete sensory manifestation, picturesqueness.

A verbal poetic image built on metabolism is an image that cannot be divided in two parts, into direct and figurative meanings, into the described object and attracted similarity. In the metabolism, the direct and figurative meanings merge; there are no similarities and transferances of signs by analogy, as in the traditional metaphor. The content of such a verbal poetic image is formed by the integration of images scattered throughout the fabric of the poetic text. Unlike a parabola, in which the images are linked by a single theme, each of them is an allegorical expression of the previous one, the centrifugal nature of the deployment of figurative space is observed in the metabolism. Each image radiates its meaning, often directly opposite, on the image located next to it, which creates a specific emotive poetic text of the postmodern.

In ancient poetics, metabola is interpreted as a plexus, a combination of modified paths and repetitions in a single figure, as a result of which the meaning is updated. A modern metabola is a holistic image, indivisible into subject and object, but revealing different dimensions in itself ${ }^{18}$.

In order to identify the features of the modern metabolism, we will consider the verbal poetic image of the American poetess, Pulitzer Prize laureate, Grace Shulman "Spending our suns like out-of-date coins, / until we reached the present-perfect tense - that have-been state / where past and future merge "(Shulman BAP, 197). At first glance, in this verbal poetic image it is difficult to determine the subject and object, the target domain and the source domain, since the conceptual schemas in it are intertwined, forming an inextricable node from the seemingly intertwined roots, creating a kind of tubers - rhizome ${ }^{19}$. Metabola is a mysterious image. Its enigmatic property is generated by cognitive dissonance, which

\footnotetext{
${ }^{16}$ Tsur R. Toward a Theory of Cognitive Poetics. Amsterdam : Elsevier Science Publishers, 1992. P. 372.

${ }^{17}$ Tsur R. Toward ... P. 20-21.

18 Эпштейн М. Н. Постмодерн в русской литературе.... С. 173.

${ }^{19}$ Eco U. The Theory of Semiotics. Bloomington : Indianna University Press, 1979. P. 74.
} 
arises due to semantic tension created by the convergence of various stylistic devices and expressive means in the same verbal poetic image: our suns - metonymy, like out-of-date coins - metaphorical comparison, spending our suns like out-of-date coins - a poetic metaphor based on conceptual metaphors and metonyms: LIGHT IS LIFE, SUN IS THE LIGHT Of LIFE, SUN stands for JOYFUL PERIOD OF HUMAN'S LIFE or TIME; TIME IS MONEY. Since the named conceptual metaphors and metonymy are basic, the cognitive grounds of which are archetypal and stereotypical schemas included in the Great Chain of $\mathrm{Being}^{20}$, the perception of the first part of the verbal poetic image does not cause difficulties. The meaning of the image "happy and carefree pastime" is singled out by analyzing the conceptual integration of values in the emergent mental space. Blending i.e. the merging of the denotative values of the tokens sun, out-of-date coin is carried out on the basis of analogical and associative mapping of semantic features of the concepts LIGHT, SUN, LIFE, TIME, MONEY. Enigmatic character is created by a metaphor: reached the present-perfect tense, as a result of constructive mapping, which causes semantic tension due to ambiguity of the nominative unit tense, meaning time in the role of a noun, and in the role of an adjective - stress. In addition, the hyphenated spelling of the presentperfect phrase creates the effect of "estrangement" according to V. Shklovsky and thus orientates the reader to the linguo-cognitive procedure of prospection - the search for a vantage point or interpretation angle, which ensures the adequate interpretation of the content of verbal poetic image. Understanding the present-perfect tense through the havebeen state and the relationship between the content of the present perfect time + stress + perfect condition $=$ unsurpassed, perfect present period of life with the metaphor-metonymy where past and future merge leads to the understanding of the content of have-been state as old age, and given that the meaning of the whole verbal image can be expressed as follows: old age is a period of life when a person on the basis of experience has comprehended the wisdom of being.

In addition to conceptual integration, the cognitive basis of the verbal poetic image-metabola is the conceptual amalgam - the exchange of meanings, not a mixture, but a suspension, not blending, alloy or merging, but their parallel coexistence, which ensures the play of different text worlds. The term amalgam is borrowed from chemistry, where it is used to explain the chemical process, which results in the formation of a suspension, a suspension of liquid and solid particles that do not dissolve,

\footnotetext{
${ }^{20}$ Lakoff, George and Turner Mark. More than Cool Reason : A Field Guide to Poetic Metaphor. Chicago : The University of Chicago Press, 1989. P. 160-170.
} 
but remain in a suspended state ${ }^{21}$. The phenomenon of amalgamation is noticed in other sciences, in physics in particular. Amalgam is an alloy of mercury with other metals ${ }^{22}$. Amalgamation is a method for extracting metals using mercury ${ }^{23}$. As a result of such a process or amalgamation, the surface of the object acquires a different look. However, over time, the amalgamated surface layer partially erases and the primordial material is visible. The term "syntactic amalgam" was introduced into linguistics by Geoge Lakoff, understanding it as the syntactic construction indecomposable, not further divisible into immediate constituents ${ }^{24}$. In the works of N.F. Alefirenko amalgamation is treated as a process of secondary nomination, leading to the emergence of a complex, consisting of several words of an indirect name ${ }^{25}$. The semantic spectrum of such a multicomponent linguistic unit determined not only by the fusion of several naming relations into one (conceptual integration, blending), but also by the interaction of various forms of reflection of reality: the primary, fixed in the semantics of the linguistic units of the primary nomination, and the secondary, which necessitates indirect nomination ${ }^{26}$. In other words, the explanation of the new meaning of the language unit is carried out through the prism of existing, known meanings. We understand the semantic space of the image as a kind of container in which various processes of interaction of the meanings of its nominative units take place.

Graphically, the configuration of the semantic space of the metabola with the rhizome interweaving of images is shown in Fig. 1.

The configuration of the semantic space of the metabolism is due to the convergence and divergence of images, interconnected by chain (convergence) and radial (divergence) connections.

Thus, the verbal poetic image created by the metabolism is an image that cannot be divided into direct and figurative meaning, the described object and the supposed similarity, it is the image of the textual worlds interplay. The sense in the metabola is formed in the process of a complex rearrangement of denotative and connotative meanings in the semantic structure of verbal poetic image. The conceptual amalgam promotes the rhizomatic interweaving of meanings and determines the preservation of the primary archetypal meaning and its interaction with new ones.

\footnotetext{
21 Большая советская энциклопедия. (В 30 томах) Гл. ред. : А.М. Прохоров. Изд.3-е. Т. 1. М. : Советская Энциклопедия, 1969. С. 503.

${ }^{22}$ Большая советская энциклопедия. ... С. 504.

${ }^{23}$ Большая советская энциклопедия..... С. 503.

24 Лакофф Дж. Лингвистические гештальты / Новое в зарубежной лингвистике. Выпуск Х. Лингвистическая семантика. М. : Прогресс, 1981. С. 350-369.

25 Алефиренко Н.Ф. Поэтическая энергия слова. Синергетика языка, сознания и культуры. М. : Academia, 2002. C. 37.

${ }^{26}$ Алефиренко Н.Ф. Поэтическая энергия слова. ... С. 38.
} 


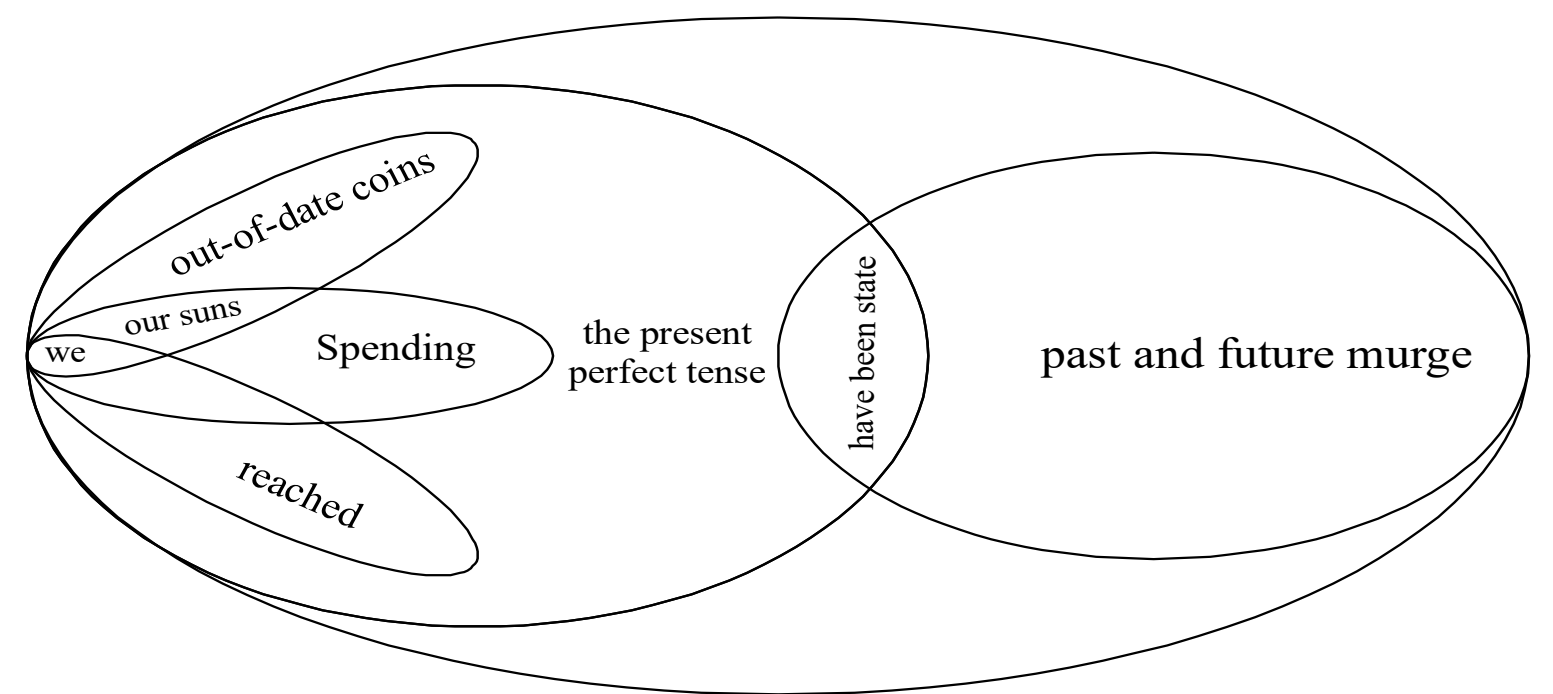

Fig. 1. The configuration of the semantic space of the verbal poetic image-metabolism of G. Shulman "Spending our suns like..."

In the light of the linguo-synergetic understanding of the language and the text world theory, "the word is an information and energy mediator and at the same time the "golden key" of cognition of the general structure of the universe, in which information and energy are primary, while substance and consciousness is secondary. But in the language consciousness, substance and energy information merge as a single whole, reflecting the general laws of the structure of man, nature, the universe.

\section{CONCLUSIONS}

This article focuses on revealing the nature of verbal poetic image from a cognitive perspective and aims at building an original typology of images in American poetry. It highlights cognitive mechanisms that lead to the emergence of new poetic images which cause a possible breakthrough in the conceptualization of the world. Contours of the image space in American poetry are revealed via the analysis of conceptual and functional properties that characterize different types of verbal poetic images. The integrative approach to the theory of imagery helped to update the techniques of conceptual analysis of verbal poetic images and to work out the new methodology of verbal poetic image analysis and imagery space reconstruction. It has been proved that besides conceptual mapping as a cognitive operation of verbal poetic image formation based on conceptual metaphor and metonymy there exist constructive mapping on different text levels.

In the formation and understanding of kainotypes, three main directions are traced. The first two relate to new verbal poetic images, the meanings of which are localized within a single word or the whole verbal poetic image, their novelty is caused either by an elaboration of the 
meanings in nominative units, or the destruction of archetypal conceptual schemas. The third way to form the kainotype is to disperse its content in the image space of the entire text.

The sense in the metabola is formed in the process of a complex rearrangement of denotative and connotative meanings in the semantic structure of verbal poetic image. The conceptual amalgam promotes the rhizomatic interweaving of meanings and determines the preservation of the primary archetypal meaning and its interaction with new ones.

\section{SUMMARY}

This article focuses on revealing the nature of verbal poetic image from a cognitive perspective and aims at building an original typology of images in American poetry. It highlights cognitive mechanisms that lead to the emergence of new poetic images which cause a possible breakthrough in the conceptualization of the world.

In the framework of cognitive linguistics a verbal poetic image is viewed as a textual construal and a cognitive structure which has two planes - conceptual and verbal. Conceptual analysis of rich empirical data obtained from contemporary American poetry suggested figuring out two groups of poetic images: the old (archetypes and stereotypes) and new ones (idiotypes and kainotypes).

Contours of the imagery space in American poetry are revealed via the analysis of conceptual and functional properties that characterize different types of verbal poetic images. It has been proved that the formation of new verbal poetic images is predetermined by cognitive operations of mapping, extension, and modification alongside with cognitive procedures of generalization, compression, intertextualization, and perspectivization.

\section{REFERENCES}

1. Аверинцев С.С., Андреев М.Л., Гаспаров М.Л., Гринцер П.А. Категории поэтики в смене литературных эпох / Историческая поэтика. Литературные эпохи и типь художественного сознания. М. : Наследие, 1994. С. 3-38.

2. Алефиренко Н.Ф. Поэтическая энергия слова. Синергетика языка, сознания и культуры. М. : Academia, 2002. 394 с.

3. Арнольд И.В. Семантика. Стилистика. Интертекст. СПб.: Изд-во С.-Петербургского университета, 1999. 444 с.

4. Бєлєхова Л.І. Словесний поетичний образ в історикотипологічній перспективі: лінгвокогнітивний аспект (на матеріалі американської поезії). Херсон: Айлант, 2002.

5. Гассан I. Чим $є$ постмодернізм і чим він стане? Літературний $\mathrm{i}$ культурний аспекти: Пер. 3 англ. / Американська література після 
середини ХХ століття: Матеріали міжнародної конференції, Київ, 25-27 травня 1999 року. К. : Довіра, 2000. С. 19-28.

6. Лакофф Дж. Лингвистические гештальты / Новое в зарубежной лингвистике. Выпуск Х. Лингвистическая семантика. М.: Прогресс, 1981. С. 350-369.

7. Лакофф Д., Джонсон М. Метафоры, которыми мы живём: Пер. с англ. / Теория метафоры. М. : Прогресс, 1990. С. 387-415.

8. Маріна О.С. Семіотика парадоксальності у когнітивнокомунікативному висвітленні. Херсон: Айлант, 2015. 298 с.

9. Шкловский В.Б. Гамбургский счет: Статьи, воспоминания, эссе. М.: Советский писатель, 1990. 544 с.

10. Эпштейн М.Н. Парадоксы новизны: О литературном развитии в XIX - XX в. М. : Советский писатель, 1988. 416 с.

11. Эпштейн М.Н. Постмодерн в русской литературе. М. : Высшая школа, 2005. 495 с.

12. Юнг К. -Г. Архетип и символ. М. : Renaissance, 1991. 306 с.

13. Eco U. The Theory of Semiotics. Bloomington: Indianna University Press, 1979. 354 p.

14. Fauconnier, Gilles. Mappings in Thought and Language. Cambridge (Mass.) : Cambridge Univ. Press., 1994. 190 p.

15. Freeman M. "Emily Dickinson and the discourse of intimacy". I Semantics of Silence in Language and Literature G. Grabher, U. Jessner (eds.). Heidelberg: Universitat C. Winter, 1996.

16. Freeman, Margaret H. Poetry and the Scope of Metaphor: Toward a Cognitive Theory of Literature. / Metaphor and Metonymy at the Crossroads. A Cognitive Perspective. Berlin, New York.: Mouton de Gruyter, 2000. P. 253-283.

17. Freeman, Margaret. Minding: Feeling, form, and meaning in the creation of poetic iconicity. /Cognitive Poetics: Goals, Gains, and Gaps. Berlin: Mouton de Gruyter, 2009. P. 169-196.

18. Lakoff, George and Mark Johnson. Philosophy in the Flesh: The Embodied Mind and its Challenge to Western Thought. N. Y. : Basic Books, 1999. 624 p.

19. Lakoff, George. Women, Fire and Dangerous Things: What Categories Reveal About the Mind. Chicago: University of Chicago Press, 1987. $614 \mathrm{p}$.

20. Lakoff, George and Turner Mark. More than Cool Reason: A Field Guide to Poetic Metaphor. Chicago: The University of Chicago Press, 1989. $190 \mathrm{p}$.

21. Rosch E. Principles of categorization /Cognition and Categorization : Ed. by E. Rosch and B. B. Lloyd. Hillsdale (N. J.): Lawrence Erlbaum Associates, 1977. 
22. Semino, Elena "Schema theory and the analysis of text worlds". Language and Literature vol. no. 2, 1995. P. 79-108.

23. Taylor J. R. Linguistic Categorization: Prototypes in Linguistic Theory. L., N.Y. : Routledge, 1995. 304 p.

24. Turner M. The Literary Mind: The Origin of Thought and Language. N.Y.; Oxford: Oxford University Press, 1998. 187 p.

25. Tsur R. Toward a Theory of Cognitive Poetics. - Amsterdam: Elsevier Science Publishers, 1992. 549 p.

26. Большая советская энциклопедия. (В 30 томах) Гл. ред. : А. М. Прохоров. Изд. 3-е. Т. 1. М. : Советская Энциклопедия, 1969.

\section{ILLUSTRATION MATERIALS}

1. AP12 - Twelve American Poets. (1961) Stephen Whicher \& Lars Anebrink.(eds.).

2. New York: Oxford University Press.

3. BBAP - Best of the Best of American Poetry 1998 (2000). Richard Howard (ed.).

4. New York; Chicago; L.: Holt, Rinehart and Winston Inc.

5. Cummings SP - Cummings E.E. (1997). Selected Poems 1923-1958. London; Boston: Faber \& Faber.

6. Frost P - Robert Frost's Poems. (1960). New York; London; Toronto: Washington Square Press, Inc.

7. MV - The Pocket Book: Modern Verse (1958). Oscar Williams. (ed.). New York : Washington Square Press, Inc.

8. NA - The Norton Anthology of American Literature: Third Edition. (1989). New York., London.: W.W. Norton \& Company.

9. Sandburg CP - Sandburg Carl (1970). The Complete Poems. SanDiego; New York; London.: Harcourt Brace Jovanovich Publishers.

10. 35 - Under 35: The New Generation of American Poets (1989). Nicholas Christopher (ed.). New York.; London.; Toronto: An Anchor Book.

11. WW - Western Wind: An Introduction to Poetry (1992). John Frederick Nims (ed.)

12. New York, San Francisco, London., etc. : McGraw - Hill, Inc.

\section{Information about the author:}

Bieliekhova L. I.,

Doctor of Philology, Professor, Professor at the Department of the English Language and Methodology of its Teaching,

Kherson State University 27, University str., Kherson, 73000, Ukraine 